\title{
Assessment of Food Safety Management Systems in the global fresh produce chain
}

\author{
Klementina Kirezieva ${ }^{a}$, Liesbeth Jacxsens ${ }^{b}$, Mieke Uyttendaele ${ }^{\mathrm{b}}$, \\ Martinus A.J.S. Van Boekel ${ }^{a}$, Pieternel A. Luning ${ }^{a, *}$ \\ ${ }^{a}$ Food Quality and Design Group, Department of Agrotechnology and Food Sciences, Wageningen University, P.0. Box 8129, NL-6700 EV Wageningen, The Netherlands \\ ${ }^{\mathrm{b}}$ Department of Food Safety and Food Quality, Laboratory of Food Preservation and Food Microbiology, Faculty of Bioscience Engineering, University of Ghent, Coupure Links, \\ 653, 9000 Ghent, Belgium
}

\section{A R T I C L E I N F O}

\section{Article history:}

Received 11 December 2012

Accepted 12 March 2013

\section{Keywords:}

Produce

Fruits and vegetables

Food Safety Management Systems

Assessment tool

\begin{abstract}
A B S T R A C T
Foodborne outbreaks appear to increase with more incidences linked to fresh produce and derived food products. This indicates inadequacies in Food Safety Management Systems (FSMSs), which are currently implemented in companies along the fresh produce chain. However, the information related to these inadequacies is restricted and little is known about the status of the FSMS. This paper describes the development of a tool for assessment of FSMS implemented in the fresh produce chain. The tool consists of indicators and grids to assess activities that are important for fresh produce, and the system output in terms of microbiological and chemical food safety (that is, pesticide residues and emerging mycotoxins). Three sets of indicators, one for each stage of the production chain (primary production, processing and trade), have been validated by experts and tested in companies. The tool enables an integral and comprehensive assessment of FSMS across the entire supply chain. Users of the tool can identify improvement opportunities and learn how to develop towards more advanced levels of activities. For research purposes differences in FSMS can be identified and linked to type of commodity, production system, country, etc.
\end{abstract}

(c) 2013 Elsevier Ltd. All rights reserved.

\section{Introduction}

For more than a decade the focus of food safety management in Europe has been on animals and animal products (Alemanno, 2010; Caduff \& Bernauer, 2006). Concomitantly, trade and consumption of produce have notably increased (EC, 2007). Foodborne outbreaks also appear to increase with more incidences linked to produce and derived food products (Lynch, Tauxe, \& Hedberg, 2009; Sivapalasingam, Friedman, Cohen, \& Tauxe, 2004; Tauxe, Doyle, Kuchenmüller, Schlundt, \& Stein, 2010). Fruits and vegetables are often consumed raw, fresh-cut or minimally processed, whereat elimination of contamination is impossible or limited. Primary production, processing and trade activities occur in diverse climates around the globe, in different administrative conditions, in a traditional, structured or industrialized food systems, and the actors in the supply chains vary from very small to very large (McCullough, Prabhu, \& Kostas, 2008). Every operator in these chains is advised to implement a specific Food Safety Management System (FSMS) (CAC, 2003). An FSMS is the result of the implementation of available and relevant quality assurance guidelines and standards (like, Codex Alimentarius, hygiene legislation, guidelines on good practices, GLOBALGAP, BRC, IFS, etc.). At primary production these FSMSs are a

\footnotetext{
* Corresponding author at: Product Design and Quality Management Group, Department of Agrotechnology and Food Sciences, Wageningen University, P.O. Box 8129, NL-6700 EV Wageningen, The Netherlands. Tel.: + 31 7482087; fax: + 317483669 .

E-mail address: Pietenel.Luning@wur.nl (P.A. Luning).
}

result from implementing good agricultural and hygienic practices, while, at processing and trade, the FSMS includes good manufacturing and hygienic practices, and HACCP-based principles. FSMS comprises the equipment, procedures, programs, tools, organizational measures, and people necessary to execute the control and assurance activities aimed at ensuring chemical and microbial safety of fresh produce.

The translation of these requirements into a company-specific system remains a challenge, because requirements and guidelines are often general in nature, not specific to the type of production, differing per region or lacking scientific base; therefore, food business operators lack guidance for the implementation into their own FSMS (Hatanaka, Bain, \& Busch, 2005; Pachepsky et al., 2011; Steele \& Odumeru, 2004; Tyrrel, Knox, \& Weatherhead, 2006).

Several studies have already indicated inadequacies in currently implemented Food Safety Management Systems (FSMSs) in fresh produce chains, related to insufficient sanitation, hygiene deficiencies, and improper production practices (Ilic, Odomeru, \& LeJeune, 2008; Ilic et al., 2012; Johnston et al., 2006; Lehto, Kuisma, Määttä, Kymäläinen, \& Mäki, 2011; Little \& Gillespie, 2008). Information is nevertheless restricted and little is known about the status of core control and assurance activities in implemented FSMS in view of the system output. Therefore, insight is needed into the status of FSMS in fresh produce chains, which is independent of the implemented legislation and quality assurance standards. For a similar purpose a diagnostic tool has been developed previously to assess microbial FSMS in the manufacturing sector of animal derived products (that is, meat 
processing and dairy companies) (Jacxsens et al., 2010; Luning, Bango, Kussaga, Rovira, \& Marcelis, 2008; Luning et al., 2009). However, the tool as such is not suitable for the specifics of the fresh produce industry, not considering specific activities associated with primary production or processing of fresh produce, such as washing, the use of irrigation water, etc. Moreover, it does not consider pertinent to fresh produce chemical hazards such as pesticides and mycotoxins.

The objective of this study was to gain insight into the activities important for (fresh) produce that determine the chemical status in terms of pesticide residues and mycotoxins, and the microbial status of the FSMS. The outcome of an international discussion forum in January 2011 helped to identify the risks of biggest concern in the fresh produce chain (Van Boxstael et al., 2013). Furthermore, the aim was to develop a diagnostic tool to enable assessment of the FSMS implemented in companies working with fresh produce and derived products across the supply chain.

\section{Materials and methods}

\subsection{Main principles for FSMS assessment}

The assessment tool for FSMS in (fresh) produce has been developed in alignment with principles for analysis of FSMS considering both technological and managerial factors (Luning \& Marcelis, 2006, 2009a). It involves the assessment of core control and assurance activities, where both types of activities contribute to the system output (Luning \& Marcelis, 2009a; Luning et al., 2008). Control activities are aimed at keeping product and process conditions within certain limits and assurance activities are focused on setting, evaluating and modifying the system (Luning \& Marcelis, 2007).

The assessment of the system output is based on information from external (i.e. audits, complaints) and internal activities (i.e. sampling information, non-conformity) for judging the FSMS (Jacxsens et al., 2010). All control and assurance activities and system output activities are assessed through indicators with corresponding grids. The indicators aim to collect information about essential aspects of an activity that gives evidence about the actual situation. The grids depict typical situations in which companies can be placed.

Control activities are grouped into three types according to their function: preventive, intervention and monitoring. Preventive control activities are aimed at preventing product contamination; intervention activities are directed towards eliminating the contamination, and monitoring activities provide information about the status of the product and the process to enable corrections (Luning et al., 2008). The assessment of core control activities distinguishes design and actual operation. Indicators for core assurance activities include defining system set-up, validation, verification, and documentation and record keeping. Four situations are specified for each indicator of control and assurance activities; these are low (level 1), basic (level 2), average (level 3), and advanced (level 4) levels. The criteria to differentiate the levels are: use of scientific knowledge, specific information, critical analysis, procedural methods, systematic activities, and independent positions (Luning et al., 2011). In the current tool, the low level reflects that an activity is not possible/applicable (for instance, that no full intervention is possible for fresh salads), or is not applied/not done, although it is possible (for example, water control), or is unknown (such as the actual operation of activities). The basic level of control activities is characterized by standard equipment, unknown capability, use of own experience/general knowledge, and incomplete methods; these result in restricted specific information, a lack of critical analysis, and a non-procedure-driven activities. The basic level of assurance activities is typified as reactive; ad-hoc; using historical data; using non-independent judgments; lacking data analysis; unstructured; and undocumented. The average level for control activities is typified as best available in practice; potentially capable equipment; methods and programs supported by suppliers; based on expert knowledge/(sector) guidelines; structured; and standardized. The average level for assurance activities is typified as active; based on expert knowledge or regulatory information; using additional analysis; regularly reported; structured; and up-to-date. The advanced level for control activities is typified as equipment, methods and programs that are tailored/modified for specific circumstances; capability that is tested; information that is specific; activities that are based on scientific sources or knowledge; activities that are procedure-driven and comprehensively reported; and measuring equipment that is standardized and internationally acknowledged. The advanced level for assurance activities is typified as pro-active; using feedback from own FSMS; using specific information sources; using own tests or trials; using independent judgments; performing additional analysis; using actual performance measurement; structured; up-to-date and extensively documented.

The four situations for the system output indicators reflect no indication on system output (level 1), poor (level 2), moderate (level 3 ), and good (level 4) system outputs. The criteria to differentiate the levels are: structured evaluation, according to very strict and specific criteria, leading to systematic detection of the food safety problems (Jacxsens et al., 2010). In the current tool, a level of 1 is given when the activity is absent, not done, or not present. Level 2 relates to limited external system evaluation, ad-hoc sampling, using only compulsory judgment criteria, and several major food safety problems because of various causes in the FSMS. Level 3 represents multiple external system evaluation, regular sampling, using several judgment criteria, and some safety concerns, but is restricted to one aspect in the functioning of the FSMS. Level 4 corresponds to comprehensive external system evaluation, structured and comprehensive sampling, using all-encompassing judgment criteria, and no safety concerns in the FSMS.

It is important to note that the tool is not an 'audit tool' or an 'inspection tool' with detailed technical questions, as used for auditing commercial standards or governmental inspections. The assessment is independent of the implemented and certified legislation, guidelines and quality assurance standards. The tool is used as a self-assessment, where users of the tool need to assess which situation best represents that of their company. The assessment tool also functions as a research tool and the data collected at various farms or food businesses, enables to identify strengths and weaknesses common for a country, subsector, or food system. The self-assessment tool is useful as an internal audit system to track the "maturity" of the systems in place. It provides insights to the users about the status of the FSMS, independently from the implemented guidelines and quality assurance standards in place. The assessment provides insight into underlying mechanisms, and shows the different ways (levels) in which activities can be implemented. It gives first indication about possible points for improvement that need to be further investigated.

\subsection{Identification of indicators and development of grids}

Any assessment tool must be reliable and valid, and we have considered this throughout the development process. We have started by identifying the content material, and then selected indicators and formulated the grid descriptions. This process was based on a comprehensive analysis of the literature addressing crucial aspects of control and assurance of the chemical and microbial safety of fresh produce. Moreover, semi-structured interviews were conducted with experts $(n=6)$ in the fields of food quality management, microbial and chemical food safety, the processing and handling of fruits and vegetables, and water technologies. The interviews aimed to confirm, discuss and modify the initially selected indicators and corresponding grid descriptions, and identify omitted indicators or issues in the grids.

\subsection{Introduction to the assessment of the FSMS}

In the beginning of the assessment an introduction was also included; this contained general questions about the companies: size, 
location, applied and certified quality assurance standards, number of employees, other activities (such as mixed farming), and training of the owner/quality assurance manager. This information can be used later on to perform a secondary analysis; for example to investigate the impact of certification, mixed farming activities, company size, and so on.

\subsection{Validation by experts}

To further validate the tool, we invited 22 experts to complete a questionnaire, in order to confirm the selected indicators with their underlying assumptions, which reflected the advanced level in the grids. The invited experts were different from those involved in selecting the indicators, and were asked to assess the indicators for relevance (does the indicator add to the understanding of FSMS performance in the fresh produce chain?); reliability (is the indicator/ question clear and unambiguous?); and validity (does the question measure important activity of FSMS in the fresh produce chain?) (de Vaus, 2001). The experts were recruited via the consortium of the EU FP7 project Veg-i-Trade. They were intentionally selected to include fresh produce experts from the industry (representatives of produce organizations), institutes/laboratories and universities. Experts from industrial organizations have been selected according to their extensive experience in fruit and vegetable production and distribution, and their experience in implementation of quality assurance standards in the sector. Moreover, they were intended to represent those for whom the topic is most salient. Experts from academia were chosen according to their years of experience and their renowned work published in scientific journals. The indicators that were found relevant by half or less than half of the experts were considered for deletion. The experts were given the opportunity to suggest new, more relevant indicators. They also attributed an importance rating to each indicator for primary production, processing and trade companies, using an interval ranking (Iacobucci \& Churchill, 2010) with a four point Likert scale (not important, somewhat important, important, very important; 0-3).

In total, 14 experts responded to the validation study (response rate: $64 \%$ ). The experts were representatives of produce organizations $(n=5)$, institutes/laboratories (4) and universities (5), from Belgium (4), Brazil (2), the Netherlands (1), Norway (2), Serbia (1), Spain (3), and Egypt (1).

\subsection{Testing in practice}

As a first test of the understandability and availability of information from companies within the produce chain, we performed assessments at three companies in a fresh-cut lettuce production chain. The first company was a small-scale farm cultivating lettuce in Belgium, and mainly supplying nearby processing plant of fresh-cut lettuce salads. This processing plant was the second participating company. It was a medium-sized processing plant for fresh-cut salads and vegetable mixes, using lettuce supplied from farms in Belgium and the Netherlands. The third company was a large wholesaler of fresh-cut salads, and was located in the Netherlands. The assessments were performed as an interview with the farm or quality assurance manager.

After the first tests, we continued with a large-scale application of the tool to further test its robustness. To help companies in selecting the most representative situation for them, we created supporting statements. All tests were aimed to check whether obtained results fit with reality (de Vaus, 2001). After each assessment the results were communicated to the participant and feedback was acquired about availability of information, understandability of the indicators and the grids, and how well the results represented the real-life situation.

\section{Results and discussion}

\subsection{Indicators and grids for the assessment of control activities}

Fig. 1 shows the structure of the assessment tool to assess the core control and core assurance activities in the FSMS, and the system output. The indicators used to assess the design of preventive, intervention and monitoring control activities, and their actual operation, along with the assurance activities, and the system output, are summed up. The overall assumption is that a more advanced level of the core activities will lead to a more predictable and controllable system output, and implies a lower risk of unexpected microbial and chemical safety problems (Luning et al., 2011; Osés et al., 2012).

\subsubsection{Preventive control activities}

The indicators of the hygienic design of the equipment and facilities, maintenance and calibration program, sanitation program, incoming material control, and personal hygiene requirements, were found relevant to assess the design of preventive measures in companies in the (fresh) produce chain. Studies in the fruit and vegetable sector have demonstrated the importance of the hygienic design of equipment and the sanitation of equipment (e.g., Lehto et al., 2011; Rapanello, Fuzihara, Nunes, Daros, \& Savignano, 2009; Todd et al., 2010), and the personal, and especially hand hygiene of workers in the field and in companies (e.g., Fonseca, 2006; Michaels \& Todd, 2005; Todd et al., 2010). Moreover, the maintenance of sprayers, packaging and other equipment (e.g., Abhilash \& Singh, 2009; Garrett, 2009), and the incoming control of materials (such as, planting materials, fertilizers, pesticides at primary production), produce and ingredients in the next chain stages (e.g., Froder et al., 2007; Leifert, Ball, Volakakis, \& Cooper, 2008) have been stated as important measures for preventing microbial and chemical contamination of fresh produce. Therefore, the indicators to assess these activities from the main principles for FSMS assessment have been included in our tool (Luning et al., 2008).

Table 1 shows the new indicators that refer to activities important to the produce sector. The indicator 'adequacy of storage facilities' addresses the way in which storage facilities are designed within a company or at a farm. Several studies underpin the importance of cooling and air condition control in preventing the growth of microorganisms and fungi (e.g. Ezeike \& Hung, 2009; Rediers, Claes, Peeters, \& Willems, 2009). Storage facilities that are able to maintain strict temperature and/or atmosphere conditions, and have been adapted to and tested for the specific circumstances better prevent the growth of microorganisms, and are considered to be at the advanced level. Typical for the average level are the best available industrial storage facilities that make it possible to control the temperature, humidity, and/or gas composition, with known but untested principal storage capacity. The basic level, on the other hand, is typified by uncontrolled storage facility conditions, which are typically ambient conditions, bulk storage, and storage in non-separated areas. 'Sophistication of supplier control' gives an indication about how companies select their suppliers in order to prevent the contamination of their inputs. Supplier control is especially important for companies that process and trade fresh produce, due to the inherent seasonality and the fact that supplies come from different world locations to provide for year-round availability. At primary production, supplier control is aimed at inputs such as pesticides, fertilizers and planting materials. Supplier selection is an important activity that segregates safe suppliers from unsafe ones, and leads to improvements in the safety of purchased initial materials (Losito, Visciano, Genualdo, \& Cardone, 2011; Starbird, 2005). The effective control of suppliers is not only achieved by establishing long-term relationships with selected suppliers, but should also be paired with regular audits and oversight (Garcia Martinez, Poole, Skinner, Illes, \& Lehota, 2006; Luning \& Marcelis, 2009b; Roth, Tsay, Pullman, \& Gray, 2008). Thus, 


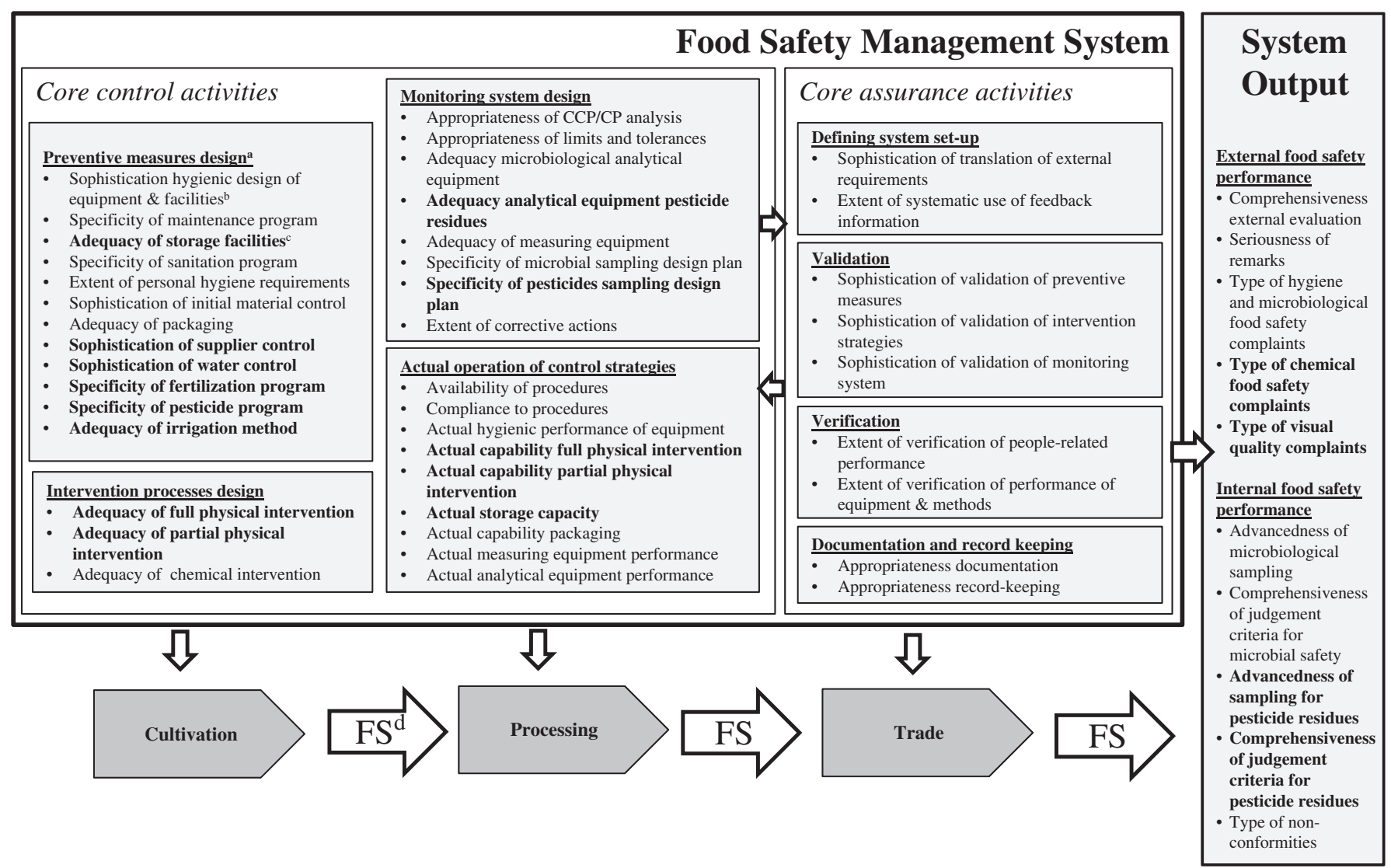

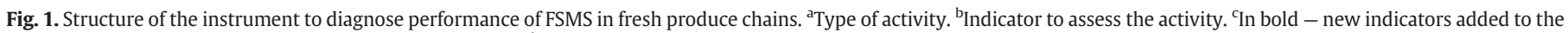
main principles for FSMS assessment (Luning et al., 2008). ${ }^{\mathrm{d}}$ Food safety output of one FSMS.

sophisticated supplier control is typified by systematic supplier selection based on pre-defined criteria, and the regular evaluation of suppliers' actual status based on audits and statistically underpinned analyses of food safety data, which is defined as the advanced level. Typical for the average level is supplier selection based on certification(s), and evaluation is based on conformity to specifications, but without the use of actual data. The basic level refers to a lack of specific selection of suppliers, and ad-hoc control. 'Sophistication of water control' gives an indication of how water quality is controlled and treated. During primary production water is used for irrigation, to apply pesticides and fungicides, to wash and rinse produce, to ice-cool, and to wash harvesting equipment. Moreover, across the whole chain workers use water for hand washing, and it can be also applied as an ingredient in processing. Studies have demonstrated and discussed that inadequacies in water control can cause food safety problems in fresh produce (e.g., Holvoet, Jacxsens, Sampers, \& Uyttendaele, 2012; Tyrrel et al., 2006). Water control with structured sampling for measuring the contamination risks in relation to the water source (or previous use) and intended use of the water is critical (Steele, Mahdi, \& Odumeru, 2005). This is valid even when potable water is used, because water quality can deteriorate at all stages through improper storage or cross-contamination (Gerba \& Choi, 2006; Gerba, Choi, Sapers, Solomon, \& Matthews, 2009). Moreover, sampling information is of high importance for selecting the most effective water treatment technologies (EHEDG, 2007; Holvoet et al., 2012; Pachepsky et al., 2011). Sophisticated water control (advanced level) is typified by water control based on statistically underpinned sampling, and treatment that is tailored and tested for efficacy in the company-specific circumstances. Typical for the average level is a water control that is based on expert knowledge or (sector) guidelines, but without structured inspections; water treatment is defined by considering the source and intended application of water. The basic level involves control based on the historical experience of water source, ad-hoc testing (upon problems), and water treatment that is not adapted and only ad-hoc applied.

Several indicators constructed specifically for companies at primary production (farms) address the fertilization program, pesticide program, and irrigation method. 'Specificity of fertilization program' gives an impression of how the application of organic fertilizers (such as manure, compost, guano, worm castings) is organized at primary production. The effectiveness of a fertilization program depends on several elements. Organic fertilizers that are disinfected for use in crops, especially in a context in which the edible part comes into direct contact with the soil (for example, leafy greens, herbs, carrots radishes, green onions, strawberries), depends on the capability of the composting process (Millner, 2009; Moral, Paredes, Bustamante, Marhuenda-Egea, \& Bernal, 2009). Studies have demonstrated that considering the actual at-site soil type, $\mathrm{pH}$, moisture factors and saturation during composting and fertilizer application contribute to preventing the survival of enteric pathogens and avoiding contamination (Jamieson, Gordon, Sharples, Stratton, \& Madani, 2002; Leifert et al., 2008; Santamaría \& Toranzos, 2003). At farms, the storage of organic fertilizers in a specific place that avoids contact with water, cultivation and handling sites further prevents cross-contamination (Coetzer, 2005). The assumption is that a sitespecific organic fertilizer program, with capable composting, and supporting instructions, better prevents cross-contamination, and positively contributes to food safety. A highly specific fertilization program (advanced level) is tailored for the specific cultivation site, wherein the capability of the composting process is tested for actual circumstances, and instructions on the storage, frequency and method of application are established based on test results. Characteristic for the average level is a program based on (sector) guidelines, using 'best standard' composting, and not tested in the own 
Table 1

Established indicators with grids at three levels to assess preventive measures design in FSMS in fresh produce chain.

\begin{tabular}{|c|c|c|c|c|}
\hline Indicators & Supporting statements & Basic level $^{\mathrm{a}}$ & Average level $^{\mathrm{a}}$ & Advanced level $^{\mathrm{a}}$ \\
\hline $\begin{array}{l}\text { Adequacy of } \\
\text { storage facilities }\end{array}$ & $\begin{array}{l}\text { When industrial storage facilities } \\
\text { are controlled, they are at an } \\
\text { average or advanced level. } \\
\text { It is crucial for advanced level } \\
\text { that storage facilities are adapted } \\
\text { (modified) and tested for the } \\
\text { specific company circumstances, } \\
\text { and actual temperature, and/or } \\
\text { relative humidity, and/or gas } \\
\text { composition are checked for } \\
\text { different circumstances. }\end{array}$ & $\begin{array}{l}\text { Uncontrolled conditions of } \\
\text { storage facilities; typically } \\
\text { ambient conditions, bulk, } \\
\text { non-separated areas }\end{array}$ & $\begin{array}{l}\text { Industrial storage facilities } \\
\text { (controlled temperature, and/or } \\
\text { humidity, and/or gas composition). } \\
\text { Information about principal storage } \\
\text { capacity is known but the actual } \\
\text { capability is not tested }\end{array}$ & $\begin{array}{l}\text { Industrial storage facilities } \\
\text { specifically modified for } \\
\text { companies' specific } \\
\text { circumstances and actual } \\
\text { storage capacity is tested } \\
\text { (e.g., for temperature, humidity, } \\
\text { gas composition) for typical } \\
\text { company circumstances }\end{array}$ \\
\hline $\begin{array}{l}\text { Sophistication of } \\
\text { supplier control }\end{array}$ & $\begin{array}{l}\text { When suppliers are regularly } \\
\text { controlled, they are at an average } \\
\text { or advanced level. } \\
\text { - It is crucial for advanced level that } \\
\text { the suppliers' control is systematic, } \\
\text { based on pre-defined criteria. }\end{array}$ & $\begin{array}{l}\text { No specific supplier selection } \\
\text { (i.e., supply based on current } \\
\text { availability); supplier control } \\
\text { is ad-hoc when problems arise }\end{array}$ & $\begin{array}{l}\text { Supplier selection based on } \\
\text { certification(s); regular evaluation } \\
\text { of suppliers is based on conformance } \\
\text { to specifications }\end{array}$ & $\begin{array}{l}\text { Systematic supplier selection } \\
\text { based on pre-defined criteria. } \\
\text { Regular evaluation of suppliers' } \\
\text { actual performance based on } \\
\text { audits and statistically } \\
\text { underpinned analysis } \\
\text { of food safety data }\end{array}$ \\
\hline $\begin{array}{l}\text { Sophistication of } \\
\text { water control }\end{array}$ & $\begin{array}{l}\text { When water control is based on } \\
\text { considerations of the source and } \\
\text { intended application of water, } \\
\text { then they are at an average or } \\
\text { advanced level. } \\
\text { - It is crucial for advanced level } \\
\text { that water control is tailored to } \\
\text { specific production circumstances } \\
\text { and is structurally implemented } \\
\text { in practice. }\end{array}$ & $\begin{array}{l}\text { Water testing is ad hoc (when } \\
\text { problems arise) and based on } \\
\text { historical experience of the } \\
\text { water source }\end{array}$ & $\begin{array}{l}\text { Water program is based on expert } \\
\text { knowledge or (sector) guidelines, } \\
\text { but is not part of structured } \\
\text { inspections; water treatment } \\
\text { considering the source and } \\
\text { intended application of water }\end{array}$ & $\begin{array}{l}\text { Water control based on } \\
\text { statistically underpinned } \\
\text { sampling and is strictly/ } \\
\text { structurally implemented in } \\
\text { (daily) practice; water treatment } \\
\text { is tailored and tested for } \\
\text { effectiveness in company-specific } \\
\text { circumstances }\end{array}$ \\
\hline $\begin{array}{l}\text { Specificity of organic } \\
\text { fertilization } \\
\text { program }^{\text {b }}\end{array}$ & $\begin{array}{l}\text { - When a fertilizer program is } \\
\text { implemented and based on } \\
\text { relevant growing conditions, } \\
\text { then it will be at an average } \\
\text { or advanced level. } \\
\text { - It is crucial for advanced level } \\
\text { that the program is tailored and } \\
\text { the actual compositing process } \\
\text { capability is tested for the } \\
\text { specific circumstances. }\end{array}$ & $\begin{array}{l}\text { Program is available and is } \\
\text { developed based on common/ } \\
\text { in-farm knowledge; capability } \\
\text { of the composting process is not } \\
\text { known; instructions for storage, } \\
\text { frequency, and method of } \\
\text { application are derived from } \\
\text { own experience }\end{array}$ & $\begin{array}{l}\text { Program is developed and } \\
\text { implemented based on (sector) } \\
\text { guidelines. Composting process } \\
\text { is based on 'best standard', but } \\
\text { not tested for the company's } \\
\text { own production circumstances. } \\
\text { Instructions about storage, } \\
\text { frequency and application based } \\
\text { on 'best practice' or advice } \\
\text { from suppliers }\end{array}$ & $\begin{array}{l}\text { Program is tailored for the specific } \\
\text { growing site and implemented; } \\
\text { composting process capability is } \\
\text { tested for actual circumstances; } \\
\text { instructions on storage, frequency } \\
\text { and method of application, based } \\
\text { on test results }\end{array}$ \\
\hline $\begin{array}{l}\text { Specificity of } \\
\text { pesticide program }\end{array}$ & $\begin{array}{l}\text { When the pesticide program } \\
\text { is specific for the type of produce } \\
\text { and approved pesticides are used, } \\
\text { then it will be at an average or } \\
\text { advanced level. } \\
\text { It is crucial for advanced level } \\
\text { that the program is modified } \\
\text { and tested for the concrete } \\
\text { cultivation site. }\end{array}$ & $\begin{array}{l}\text { Pesticide program is available } \\
\text { and developed based on common } \\
\text { knowledge; no information } \\
\text { about approval status of applied } \\
\text { pesticides; instructions about } \\
\text { storage, application, and } \\
\text { frequency derived are based } \\
\text { on own experience }\end{array}$ & $\begin{array}{l}\text { Pesticide program is developed and } \\
\text { implemented based on expert } \\
\text { knowledge (advice from suppliers, } \\
\text { sector organization); common } \\
\text { approved pesticides for type of } \\
\text { produce; instructions derived } \\
\text { from information on label, advice } \\
\text { from suppliers }\end{array}$ & $\begin{array}{l}\text { Scientific based site-specific } \\
\text { program implemented, tested } \\
\text { in companies' specific } \\
\text { circumstances, and using } \\
\text { approved pesticides; specific } \\
\text { instructions about storage, } \\
\text { application and frequency }\end{array}$ \\
\hline $\begin{array}{l}\text { Adequacy of } \\
\quad \text { irrigation method }^{\mathrm{b}}\end{array}$ & $\begin{array}{l}\text { When the irrigation method } \\
\text { is specifically aimed at preventing } \\
\text { microbial contamination, then it } \\
\text { will be at an average or } \\
\text { advanced level. } \\
\text { - It is crucial for advanced level } \\
\text { that contact with the edible } \\
\text { part is avoided, in order } \\
\text { to better prevent microbial } \\
\text { contamination. }\end{array}$ & $\begin{array}{l}\text { Common surface irrigation } \\
\text { methods such as gravity-flow/ } \\
\text { flood/furrow and sprinkler } \\
\text { irrigation }\end{array}$ & $\begin{array}{l}\text { Irrigation methods where water } \\
\text { is applied directly onto the soil/plant } \\
\text { roots such as drip/trickle irrigation }\end{array}$ & $\begin{array}{l}\text { Irrigation methods that reduce } \\
\text { microbial contamination by } \\
\text { avoiding contact with edible } \\
\text { part (subsurface irrigation } \\
\text { methods, where permanently } \\
\text { or temporarily buried dripper } \\
\text { line is used below the plant roots) }\end{array}$ \\
\hline
\end{tabular}

\footnotetext{
a Situations $1,2,3$, and 4 correspond to the following levels:
}

- Advanced level (situation 4) $\rightarrow$ scientifically underpinned (accurate, complete), stable, predictable, and tailored for the specific food production situation.

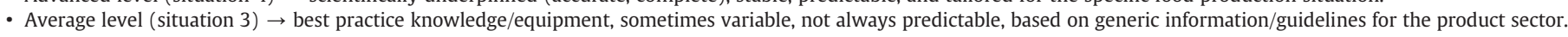

- Basic level (situation 2) $\rightarrow$ lack of scientific evidence, use of company experience/history, variable, unknown, unpredictable, based on common materials/equipment.

- Low level (situation 1) $\rightarrow$ absent, not applicable, unknown.

b Indicator applicable only at primary production.

production field, while the basic level refers to a program based on own or common knowledge, with unknown composting capability and instructions based on experience.

The indicator 'specificity of pesticide program' provides insight into the use of pesticides during fruit and vegetable production, and how it is designed to prevent the occurrence of pesticide residues in the final product. The effectiveness of pesticide management depends on selecting and applying chemicals that are effective in the specific situation (e.g. Abhilash \& Singh, 2009; Gentz, Murdoch, \& King, 2010; Olivet, Val, \& Usera, 2011). An effective program is based on an iterative process of pest identification, sampling, analysis, management alternatives (chemicals and their application), implementation, and re-evaluation (Siddiqi, 2010). Therefore, the situation is considered as advanced level when a site-specific, scientifically based program is in place, tested in the companies' specific circumstances and uses approved pesticides, Typical of the average level is a pesticide 
program based on expert knowledge (advice from suppliers, sector organization), which uses approved pesticides. The basic level programs are based on common knowledge, with no information about the approval status of applied pesticides.

Further on, 'adequacy of irrigation method' indicates the risk of microbiological contamination due to water application. Irrigation practices have a critical influence on product safety, especially when a water source of uncertain quality is used (Gerba \& Choi, 2006). Subsurface irrigation methods, where a permanently or temporarily buried dripper line or drip tape is placed below the plant roots, do not provide for contact with the edible parts of produce, thus preventing contamination (James, 2005; Oron, Campos, Gillerman, \& Salgot, 1999; Tyrrel et al., 2006). This is typified in our tool as advanced level. Common for the average level is when water is applied on the surface, close to the roots of the plants - for example through tubes. The basic level refers to common surface methods such as sprinklers and flood irrigation, which have been shown to contribute to crop contamination (Alum, Enriquez, \& Gerba, 2011; Gerba \& Choi, 2006; Stine, Song, Choi, \& Gerba, 2005).

\subsubsection{Intervention activities}

Next in the tool we addressed 'intervention processes', which, according to the main principles for FSMS assessment are aimed at inactivating or eliminating hazards in order to reduce them to acceptable levels (Luning et al., 2008). In fresh produce they may be physical (such as thermal treatments, irradiation, high-pressure) or chemical (disinfection by e.g. chlorine, ozone) interventions. We distinguish indicators for partial and full physical intervention. By partial physical intervention we are referring to processes that are aimed at reducing the microbial load (such as disinfection, the removal of outer leaves, sorting out for molds or other visual contamination), which could be applied at any point of the fresh produce chain. Within full intervention, we are addressing processes that inactivate or eliminate microorganisms to acceptable levels, such as heat treatments (such as blanching, pasteurization, sterilization, drying), and which can be applied only during processing. The assumption behind the indicators measuring 'adequacy of intervention' is that the effectiveness of any intervention treatment is dependent on its suitability to the particular product and concrete production circumstances. Studies have demonstrated that inadequate intervention equipment or ineffective methods may lead to food safety problems in fruit and vegetable products (e.g., Gil, Selma, López-Gálvez, \& Allende, 2009; Li, Brackett, Chen, \& Beuchat, 2002). Typical for the basic level is the use of general, non-product-specific intervention, without known capability, while the average level uses 'best standard' productspecific intervention, with capability that is described in specifications (provided by equipment suppliers), but is not tested for the company's own production. The advanced design of these activities is defined as being modified for the company-specific circumstances and the actual capability tested.

\subsubsection{Monitoring system design}

Important elements of monitoring include the identification of hazards, the evaluation of risks, the allocation of critical control and other points in which hazards need to be controlled (Hulebak \& Schlosser, 2002). Companies active in the fresh and minimally processed produce sector have been using the HACCP approach for years; however, in this sector no definite inactivation step can be achieved, and efforts are mainly directed towards the reduction of potential contamination through pre-requisite programs (e.g. GMP) or partial intervention (da Cruz, Cenci, \& Maia, 2006). Hazards are commonly addressed through control points $(\mathrm{CP})$ to prevent the growth of pathogens, microbiological or chemical contamination (in practice also called critical prevention points). Various studies have demonstrated that inadequacies in the monitoring systems can cause food safety problems in the production of fruits and vegetables (e.g. Hedberg et al., 1999; Tyrrel et al., 2006). Therefore, the indicators 'appropriateness of CCP or CP analysis', 'appropriateness of limits and tolerances assessment', 'adequacy of measuring equipment' and 'extent of corrective actions' have been found useful for assessment of the FSMS within the fresh produce chain. Furthermore, the indicators about analytical methods for microbiological hazards and microbiological sampling plan address the microbial analysis conducted in the companies in the chain (Table 2). Studies have stressed the importance of these monitoring issues in fresh produce production, especially postharvest (Blanc, 2006; Holvoet et al., 2012; ICMSF, 1986; Lehto et al., 2011). Typical for advanced levels of the indicators for monitoring systems design is the use of scientific knowledge, which is adapted to own production, systematic and tested (by challenge testing, for example) for the specific food production. The average levels are typified by the use of the 'best available' knowledge for the sector, but are not tailored for own production, whereas, at low levels, scientific support and a systematic approach are lacking (Luning et al., 2008).

To address chemical food safety in monitoring, we defined the indicators 'adequacy of analytical methods for pesticide residues' and 'specificity of sampling plan for pesticide residues'. Within the latter we refer to the samples for routine analysis of the pesticide residues that could be taken by the company itself or by a third party. The trustworthiness of the sampling data is determined by the quality of the analytical methods used for the analysis (Cox, 2002; Thorpe \& Reynolds, 1996). An advanced level for this activity is attributed to samples analyzed by an accredited laboratory, using internationally accredited methods (Table 2).

\subsubsection{Actual operation of control activities}

The indicators 'availability of procedures' and 'actual compliance to procedures' (Fig. 1) have been found useful for fresh produce, in line with studies discussing the variability of sanitary behavior among fresh produce workers (Michaels \& Todd, 2005; Sagoo, Little, \& Mitchell, 2003; Soon \& Baines, 2012). Typical for the advanced level is procedures that are available at location, and are easy to understand, accurate, and specific to the workers who will follow them. Similarly, for compliance to procedures the advanced level is typified by workers who have a good understanding of their tasks and the procedures, and they are internalized (Luning et al., 2008). The basic level is characterized by procedures that are difficult to understand, are not updated, and their availability is limited, and tasks that are executed according to the worker's own insights. The average level refers to easily understandable procedures, which are available on location and updated on an ad-hoc basis, and compliance based on habits but controlled on a regular basis (Luning et al., 2008).

The operational capability of crucial control equipment and facilities (for example, intervention equipment, packaging equipment, cooling and storage facilities) (Luning et al., 2008) also has an important impact on the actual system output in fresh produce (Allende, Selma, López-Gálvez, Villaescusa, \& Gil, 2008; Chua, Goh, Saftner, \& Bhagwat, 2008 Rediers et al., 2009). Stable equipment performance at different production situations, which is systematically monitored and analyzed, is characteristic for the advanced level, whereas regularly unstable equipment with unexplainable deviations, which is not monitored or analyzed, is typical for the basic level (Luning et al., 2008).

\subsection{Indicators and grids for the assessment of assurance activities}

The indicator 'sophistication of translating external requirements' focuses at assessing how the external assurance requirements are transposed into a company's own FSMS. When new requirements need to be implemented, the current activities in the system have to be compared and modified accordingly. Requirements and guidelines for the fresh produce sector can be general, and also commodity specific 
Table 2

Expert validation of indicators for control activities for Primary Production, Processing and Trading companies: relevance points and importance rating (mean and standard deviation).

\begin{tabular}{|c|c|c|c|}
\hline \multirow[t]{2}{*}{ Indicator } & \multirow[t]{2}{*}{ Assumed mechanism } & $\begin{array}{l}\text { Relevance } \\
(\mathrm{n}=14)\end{array}$ & $\begin{array}{l}\text { Importance rating } \\
(0 \rightarrow 3, \text { not to very } \\
\text { important })\end{array}$ \\
\hline & & $\begin{array}{lll}\text { PP } & \text { P } & \text { T }\end{array}$ & $\mathrm{PP}$ \\
\hline
\end{tabular}

Preventive measures design

Sophistication hygienic design equipment \& facilities

Specificity of maintenance and calibration program ${ }^{\mathrm{b}}$

Adequacy of storage facilities

Specificity of sanitation program $^{\mathrm{b}}$

Extent of personal hygiene requirements ${ }^{\mathrm{b}}$

Sophistication of incoming materials control ${ }^{\mathrm{a}}$

Adequacy of packaging ${ }^{\mathrm{b}}$

Sophistication of water control

\section{Sophistication of supplier control \\ Specificity of fertilizer program $^{\mathrm{d}}$ \\ Specificity of pesticide program $^{\text {d }}$ \\ Adequacy of irrigation method $^{d}$}

Intervention processes design Adequacy of full physical intervention $^{\mathrm{e}}$

Adequacy of partial physical intervention

Adequacy of chemical intervention ${ }^{\mathrm{b}, \mathrm{e}}$

Monitoring systems design Appropriateness of $\mathrm{CCP} / \mathrm{CP}$ analysis $^{\mathrm{b}}$

Appropriateness of limits and tolerances assessment ${ }^{\mathrm{b}}$

Adequacy of microbiological analytical methods ${ }^{\mathrm{b}}$

Adequacy of analytical methods for pesticides ${ }^{a}$

Adequacy of measuring equipment $^{\mathrm{b}}$

Specificity of microbiological sampling plan ${ }^{\mathrm{b}}$

Specificity of pesticides' sampling plan ${ }^{\mathrm{a}}$

Extent of corrective actions ${ }^{\mathrm{b}}$
Advanced hygienic design of critical equipment and facilities tailored and tested for specific circumstances decreases the chance of (cross-) contamination and enables effective cleaning, which will positively contribute to food safety

Structural and tailored programs for maintenance with specific instructions about frequency and tasks will cause fewer unexpected safety problems due to unreliable equipment, which will positively contribute to food safety

Adequate storage facilities maintain strict temperature and/or atmosphere conditions and prevent growth of microorganisms, which will positively contribute to food safety Specific, full-step and tailored sanitation programs with appropriate cleaning agents, supported with appropriate instructions better prevent contamination, which will positively contribute to food safety

High and specific personal hygiene requirements and specific instructions reduce the chance of contamination, which will positively contribute to food safety Systematic and adequate incoming material control will prevent (high and variable initial) acceptance of contaminated incoming materials, which will reduce the chance of (cross-) contamination of the production process, which will positively contribute to food safety Packaging equipment with adequate and tested capability enables less unpredictable process variation and better compliance to standards, which will positively contribute to food safety Systematic monitoring and water treatment that considers the water source and intended application of the water will prevent (high and variable initial) contamination, which will positively contribute to food safety

Systematic supplier selection and evaluation will lead to more predictable safety levels of incoming materials, which will positively contribute to food safety

Site-specific organic fertilizer program, with capable composting, supported by appropriate instructions, better prevents cross-contamination, which will positively contribute to microbiological food safety

Specific and tailored pesticides program with specific instructions and use of authorized chemical(s) and/or methods helps to better prevent pesticide residues, which will positively contribute to chemical food safety

Irrigation methods that specifically aim to avoid direct contact with edible part of produce will better prevent microbiological contamination, which will positively contribute to food safety

Full intervention equipment that is specific and has had its capability tested enables less unpredictable process variation and better compliance to standards, which will positively contribute to food safety

Specific and tested partial physical intervention enables less unpredictable process variation and better compliance to standards, which will positively contribute to food safety Specific chemical intervention methods better reduce the contamination load of (initial) materials, which will positively contribute to food safety

Higher level of scientific evidence and a more systematic way of analyzing hazards and associated risk, together with actual testing of CCP and CPs, will result in more reliable and accurate control points, which will positively contribute to food safety

More complete specification of standards and tolerances for critical process and product parameters, supported by scientific data, will result in more accurate determination and adjustment of product/process deviations, which will positively contribute to food safety Sensitive, specific, repeatable, reproducible and rapid methods to assess pathogens will result in more adequate determination of pathogens, which will positively contribute to food safety

More sensitive, specific, repeatable, reproducible and rapid methods to assess chemical contaminants will result in more adequate determination, which will positively contribute to food safety

Accurate and responsive equipment to monitor critical process and or product parameters will result in more adequate monitoring, which will positively contribute to food safety

A statistically underpinned and tailored sampling plan increases the reliability of information about the actual product/process status, which will positively contribute to food safety A statistically underpinned and tailored sampling design increases the reliability of information $11 \quad 12 \quad 12 \quad 2.3\left(\begin{array}{llll}1.0 & \mathbf{2} & \mathbf{2 . 6}(0.5) & 2.4(0.7)\end{array}\right.$ about the actual product/process status, which will positively contribute to food safety

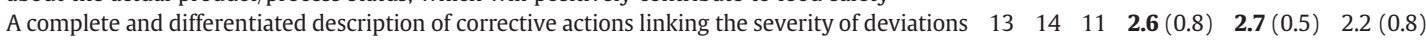
to the type of corrective actions will positively contribute to food safety

a Modified from the original concept for assessment of FSMS.

b Indicators retained from the original concept for assessment of FSMS (Luning et al., 2008).

c In bold - new indicators.

d Indicator relevant only for primary production.

e Indicator relevant only for processing. 
(e.g. BRC, 2008; CAC, 2010a; UnitedFresh, 2008; WesternGrowers, 2006). In the coming years more demands are expected to be placed on the sector due to increased concerns and augmented production and consumption of produce and derived products (e.g., Havelaar et al., 2010; Kleter \& Marvin, 2009; van Asselt, Meuwissen, van Asseldonk, Teeuw, \& van der Fels-Klerx, 2010). Sophisticated translation (advanced level) is typified by a pro-active approach, which is based on systematic analysis of possible changes (such as new legislation, new branch demands) and evaluated on critical aspects of the producer's own food production system (Luning et al., 2009). The basic level is characterized by reactive translation of stakeholder requirements, after problems or after changes in legislation or demands (Luning et al., 2009). Moreover, the modification and adaptation of the FSMS is not a one-time activity and the indicator 'extent of systematic use of feedback information to improve the FSMS' was included to address the ongoing changes derived from the system itself. Systematic analysis of information from validation and verification reports, and translations into concrete FSMS modifications that are established in clear procedures with assigned responsibilities, and well documented, are typical of the advanced level, while the activities at the basic level are done after problems (Luning et al., 2009).

The indicators for validation assess the 'sophistication of validating preventive measures', 'intervention methods', and 'monitoring systems'. For verification they address the 'extent of verifying people-related performance', and 'equipment and method-related performance'. Both types of activities are crucial for the preventive approach, since they check every step of the process for effectiveness in advance (Luning \& Marcelis, 2007). They are especially important for fresh or minimally processed produce, where full intervention is not possible (da Cruz et al., 2006). An example of this is the washing of vegetables during fresh-cut processing, which is defined as partial intervention in our tool, and is often ineffectively done in practice, because factors influencing its effectiveness are not fully understood by companies and validation is ineffective (Holvoet et al., 2012; Seymour, 1999). The advanced levels are typified by systematic and independent (that is, by external expert) validation, which is based on specific scientific sources, and conducted systematically and after modifications in the FSMS, while the basic levels are validated on an ad-hoc basis, based on historical knowledge, and only judged by internal to the company people (Luning et al., 2009). Next, verifying the compliance of the people and methods has been stated as an important activity in meeting safety export standards at primary production (Jaffee \& Masakure, 2005; Okello \& Swinton, 2007), but is also important within processing and trade companies for guaranteeing product safety (Garrett, 2009; Hentges, Schmidt, \& Rodrick, 2005; Hofer, Gardner, \& Ford, 2005; Hurst, 2007). The advanced levels are typified by the use of analysis and by actual testing or observations, which are done by independent experts, with defined frequency, and upon system modifications, while the basic level verification is based upon checking for presence, which is conducted on an ad-hoc basis by people who work in the system (Luning et al., 2009).

Finally, the indicators 'appropriateness of record-keeping system' and 'appropriateness of documentation system' address the activities that are aimed at keeping knowledge about the FSMS by collecting product and process data and keeping information in the form of procedures, instructions, manuals, etc. The advanced levels are typified by structured and complete documentation, which is keptup-to-date with assigned responsibilities, and is centrally organized, automated and online available for all, while the basic levels are characterized by unstructured and ad-hoc documentation and record keeping (Luning et al., 2009). The above-described assurance activities are crucial for any FSMS in providing transparency and confidence to stakeholders that the system is designed and operating according to the necessary standards (Taylor, Kastner, \& Renter, 2010; Yudin, 2011).

\subsection{Indicators and grids for the assessment of the system output}

In Fig. 1, indicators for the external and internal system output are listed. Similarly to the other food sectors, external audits of companies in the fresh produce chain can be conducted by various parties: national authorities perform (regular) inspections, and accredited bodies conduct audits against various quality assurance standards, such as GLOBALGAP, BRC, IFS, etc. For this reason, the indicators 'comprehensiveness of external evaluation' and 'seriousness of remarks' have been found useful to assess the status of FSMS in the fresh produce chain. The good output levels are typified by audits or inspections performed by several accredited third parties and national food safety agencies, with no major remarks, or only minor remarks. On the contrary, the poor output is characterized by inspections performed by only the national food safety agency, with major remarks on various aspects of the FSMS (Jacxsens et al., 2010). Another indicator is addressing the 'type of microbiological safety and hygiene-related complaints' from client companies. Complaint registration in companies, as well as the analysis of these, can give an important feedback information for the improvement of the FSMS, and increased attention is given to this in quality assurance standards for the food industry, without bypassing the fresh produce sector (GlobalGAP, 2012; Trienekens \& Zuurbier, 2008). The good output level is typified by a lack of complaints, while poor output is characterized by various complaints which can be dedicated to multiple problems in the FSMS (Jacxsens et al., 2010).

The indicators 'advancedness of product sampling', 'comprehensiveness of microbiological criteria', and 'type of non-conformities' aim to provide intra-company information about the output of the system. Within non-conformities, we include initial materials, intermediate or final products that do not meet the required specifications (identified by the company itself) towards hygiene, pathogens, mycotoxins, pesticide residues, or quality aspects (i.e. mold, rot, bruises), and the products are not delivered to the customers. Taking samples and registering non-conformities enable companies in the fresh produce sector to judge the performance of their quality management systems (Fouayzi, Caswell, \& Hooker, 2006). Typical for good output is a structured company-specific sampling plan, which is conducted on the final food product, initial material(s) and environmental samples, and interpreted using a combination of legal criteria, requirements, specifications by external parties and additional company-specific specifications. Poor output is characterized by ad-hoc sampling (upon request), which is only conducted on the final food product, and is interpreted using a restricted number of criteria (e.g. only legal criteria) (Jacxsens et al., 2010).

We have constructed four similar indicators that specifically give indication about the chemical safety output. 'Advancedness of product sampling for pesticide residues' and 'comprehensiveness of judgment criteria for pesticide residues' assess the type of samples taken and how they are used to judge the chemical safety status of the FSMS. Testing for pesticide residues can be done on a governmental level, by external organizations (such as branch organizations or, retailers), or by producers themselves. Typical for good output is structured sampling, at a company level, and regular monitoring at a sector level (which is statistically underpinned). The moderate output is characterized by structured sampling, with fixed frequency, at company level or sector level, and poor output is based on ad-hoc sampling, due to demands of customers or legislation, which is done on particular lot(s)/batch(es). The results can be interpreted based on pesticide residue limits set in guidelines or legislation (e.g., CAC, 2010b; EC, 2005), sometimes in conjunction with even more stringent private codes (Okello \& Swinton, 2010).

'Type of customer complaints to chemical safety (pesticide residues and mycotoxins)' and 'type of customer complaints regarding visual quality' of final products address the chemical safety related complaints. The latter include complaints regarding molds, rotten 
parts, bruises, etc. and give an important indication about problems in the quality system. Complaint registration provides feedback information from client companies about the operation of a quality assurance system (Fouayzi et al., 2006; Garcia Martinez et al., 2006). In the case of visual quality at the end of the supply chain, final consumer complaints can also be included.

\subsection{Validation by experts}

Table 2 shows the results from the expert validation of control activities. Overall, all indicators received higher importance scores for processing, compared to primary production and trade. This could be related to the more common use of HACCP-based systems in processing companies (da Cruz et al., 2006). Indicators for the design of preventive measures received scores for importance of between 1.8 and 2.9, and for processing the scores ranged between 2.6 and 2.9. At primary production, the highest scores were received for hygienically designed equipment (2.6), a sanitation program (2.6), incoming material control (2.7), packaging (2.8), water control (2.8), supplier control (2.6), and irrigation methods (2.6). At trade, the highest importance scores were given for storage facilities (2.8), personal hygiene requirements (2.5) and supplier control (2.7). The indicators for full and chemical intervention were excluded for primary production and trade, where they could not be applied, but at processing they received an importance rating of 2.6. For monitoring activities, at processing the mean scores were between 2.6 and 2.9, while the scores were lower for the rest of the chain - between 1.7 and 2.6 for primary production, and between 2.2 and 2.6 for trade. Fewer than seven experts supported the relevance of the indicator 'adequacy of measuring equipment' for both primary production and trade. However, we preserved this indicator in the tool for trade, because measuring equipment is commonly used for measuring temperature and other atmospheric conditions in storage facilities. Moreover, after tests in farms, this indicator was also preserved for primary production, where measuring equipment is also used in areas such as storage and water control. For primary production and trade, the highest scores (2.6 and 2.9) were given for analytical methods. Furthermore, at primary production a high score (2.6) was received for corrective measures.

Table 3 shows the results from the expert validation of assurance activities. Experts gave lower points to the relevance of the indicator for validating the monitoring system at primary production. Scores were again higher for processing (between 2.6 and 2.9) than for primary production (1.4-2.6) and trade (2.1-2.8). High scores were given for documentation and record-keeping for all the three chain stages (2.6 and 2.5 for primary production; 2.9 for processing and 2.8 for trade).

Table 4 shows the results from the expert validation for the system output. Importance rating scores were again higher at processing (2.1-2.8) than for primary production (2.1-2.6) and trade (2.1-2.7). Highest scores at processing were given for microbiological complaints (2.8), microbiological sampling (2.7), and non-conformities

Table 3

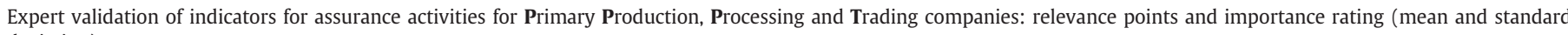
deviation).

\begin{tabular}{|c|c|c|c|c|c|c|c|}
\hline \multirow[t]{2}{*}{ Indicator $^{\mathrm{a}}$} & \multirow[t]{2}{*}{ Assumed mechanism } & \multicolumn{3}{|c|}{$\begin{array}{l}\text { Relevance } \\
(\mathrm{n}=14)\end{array}$} & \multicolumn{3}{|c|}{$\begin{array}{l}\text { Importance rating } \\
(0 \rightarrow 3, \text { not to very important })\end{array}$} \\
\hline & & $\mathrm{PP}$ & $\mathrm{P}$ & $\mathrm{T}$ & $\mathrm{PP}$ & $\mathrm{P}$ & $\mathrm{T}$ \\
\hline \multicolumn{8}{|l|}{ Defining system set-up } \\
\hline $\begin{array}{l}\text { Sophistication of translation of external } \\
\text { requirements }\end{array}$ & $\begin{array}{l}\text { Systematic and precise translation of stakeholder requirements will } \\
\text { result in suitable requirements on the FSMS, which will contribute to } \\
\text { assurance of product safety }\end{array}$ & 14 & 12 & 12 & $2.4(0.7)$ & $2.6(0.8)$ & $2.4(0.7)$ \\
\hline $\begin{array}{l}\text { Extent of systematic use of feedback } \\
\text { information }\end{array}$ & $\begin{array}{l}\text { Systematic use of valid feedback information from control system will } \\
\text { result in appropriate system modifications, which will contribute to } \\
\text { assurance of product safety }\end{array}$ & 14 & 14 & 13 & $2.5(0.7)$ & $2.9(0.4)$ & $2.7(0.6)$ \\
\hline \multicolumn{8}{|l|}{ Validation } \\
\hline $\begin{array}{l}\text { Sophistication of validation of preventive } \\
\text { measures }\end{array}$ & $\begin{array}{l}\text { A scientific-evidence-based, systematic, and independent validation } \\
\text { of the effectiveness of selected preventive measure will result in an } \\
\text { effective FSMS, which will positively contribute to assurance of } \\
\text { product safety }\end{array}$ & 13 & 14 & 13 & $2.4(0.6)$ & $2.9(0.4)$ & $2.3(0.5)$ \\
\hline $\begin{array}{l}\text { Sophistication of validation of intervention } \\
\text { strategies }\end{array}$ & $\begin{array}{l}\text { A scientific-evidence-based, systematic, and independent validation } \\
\text { of the effectiveness of selected intervention processes will result in } \\
\text { an effective FSMS, which will positively contribute to assurance } \\
\text { of product safety }\end{array}$ & 12 & 14 & 13 & $2.3(0.8)$ & $2.8(0.4)$ & $2.2(0.7)$ \\
\hline $\begin{array}{l}\text { Sophistication of validation of monitoring } \\
\text { system }\end{array}$ & $\begin{array}{l}\text { A scientific-evidence-based, systematic, and independent validation } \\
\text { of CCPs' and/or CPs' determination and establishment of control circles } \\
\text { will result in an effective FSMS, which will positively contribute to } \\
\text { assurance of product safety }\end{array}$ & 7 & 13 & 12 & $1.4(1.2)$ & $2.8(0.4)$ & $2.4(0.6)$ \\
\hline \multicolumn{8}{|l|}{ Verification } \\
\hline $\begin{array}{l}\text { Extent of verification of people-related } \\
\text { performance }\end{array}$ & $\begin{array}{l}\text { Specific, systematic, and independent verification of procedure characteristics } \\
\text { and compliance will result in a reliable FSMS, which will positively contribute } \\
\text { to assurance of product safety }\end{array}$ & 13 & 14 & 12 & $2.4(0.6)$ & $2.6(0.5)$ & $2.3(0.7)$ \\
\hline $\begin{array}{l}\text { Extent of verification of performance } \\
\text { of equipment and methods }\end{array}$ & $\begin{array}{l}\text { Specific, systematic, and independent verification of equipment and methods } \\
\text { performance will result in a reliable FSMS, which positively contributes to the } \\
\text { assurance of product safety }\end{array}$ & 12 & 14 & 11 & $2.1(0.7)$ & $2.8(0.4)$ & $2.1(0.8)$ \\
\hline \multicolumn{8}{|l|}{ Documentation } \\
\hline Appropriateness documentation & $\begin{array}{l}\text { An integrated, up-to-date and accessible documentation system will improve } \\
\text { information (experience, scientific knowledge, legislative requirements) } \\
\text { supply for FSMS, which will support validation and verification activities, } \\
\text { which will positively contribute to the assurance of product safety }\end{array}$ & 14 & 14 & 13 & $2.6(0.6)$ & $2.9(0.4)$ & $2.8(0.4)$ \\
\hline Appropriateness record-keeping system & $\begin{array}{l}\text { A structured, integrated, and accessible record-keeping system will support } \\
\text { validation and verification activities, which will positively contribute to the } \\
\text { assurance of product safety }\end{array}$ & 14 & 14 & 14 & $2.5(0.7)$ & $2.9(0.4)$ & $2.8(0.4)$ \\
\hline
\end{tabular}

a All indicators are retained from the original concept (Luning et al., 2009). 
Table 4

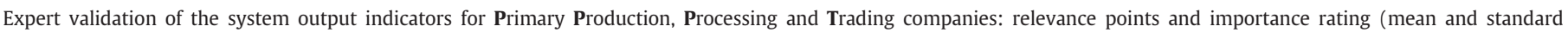
deviation).

\begin{tabular}{|c|c|c|c|c|c|c|c|}
\hline \multirow[t]{2}{*}{ Indicator } & \multirow[t]{2}{*}{ Assumed mechanism } & \multicolumn{3}{|c|}{$\begin{array}{l}\text { Relevance } \\
(\mathrm{n}=14)\end{array}$} & \multicolumn{3}{|c|}{$\begin{array}{l}\text { Importance rating } \\
(0 \rightarrow 3, \text { not to very } \\
\text { important })\end{array}$} \\
\hline & & $\mathrm{PP}$ & $\mathrm{P}$ & $\mathrm{T}$ & $\mathrm{PP}$ & $\mathrm{P}$ & $\mathrm{T}$ \\
\hline \multicolumn{8}{|l|}{ External FSMS performance } \\
\hline Comprehensiveness external evaluation $^{a}$ & $\begin{array}{l}\text { Evaluation by both national food safety agencies and certification audit } \\
\text { by a third party provides a comprehensive external FSMS evaluation }\end{array}$ & 14 & 14 & 13 & $2.6(0.5)$ & $2.5(0.5)$ & $2.2(0.7)$ \\
\hline Seriousness of remarks ${ }^{a}$ & $\begin{array}{l}\text { Positive evaluations (without serious remarks) of the FSMS by various } \\
\text { national food safety agencies and accredited third parties indicate a good } \\
\text { safety performance (i.e., all requirements of the stakeholders are met) }\end{array}$ & 14 & 14 & 14 & $2.4(0.6)$ & $2.4(0.5)$ & $2.4(0.6)$ \\
\hline $\begin{array}{l}\text { Type of hygiene and microbiological } \\
\text { food safety complaints }{ }^{\text {b }}\end{array}$ & $\begin{array}{l}\text { Low number or no complaints about hygiene and microbiological food } \\
\text { safety indicate a good performance when a good complaint registration } \\
\text { and evaluation system are in place }\end{array}$ & 13 & 14 & 12 & $2.5(0.5)$ & $2.8(0.4)$ & $2.6(0.6)$ \\
\hline Type of chemical food safety complaints ${ }^{c}$ & $\begin{array}{l}\text { Low number or no complaints about chemical food safety indicate a good } \\
\text { performance when a good complaint registration and evaluation system } \\
\text { are in place }\end{array}$ & 14 & 14 & 13 & $2.6(0.5)$ & $2.5(0.5)$ & $2.7(0.5)$ \\
\hline Type of visual quality complaints & $\begin{array}{l}\text { Low number or no complaints of visual quality indicate a good performance } \\
\text { when a good complaint registration and evaluation system are in place }\end{array}$ & 11 & 12 & 12 & $2.0(1.0)$ & $2.1(0.8)$ & $2.2(0.8)$ \\
\hline \multicolumn{8}{|l|}{ Internal FSMS performance } \\
\hline $\begin{array}{l}\text { Advancedness of microbiological } \\
\text { sampling }^{\mathrm{a}}\end{array}$ & $\begin{array}{l}\text { Structured sampling and different types of samples provides a more } \\
\text { comprehensive and accurate indication of the actual microbiological } \\
\text { performance of your FSMS }\end{array}$ & 11 & 14 & 10 & $2.1(0.8)$ & $2.7(0.4)$ & $2.1(0.9)$ \\
\hline $\begin{array}{l}\text { Comprehensiveness judgment criteria } \\
\text { microbial FS }\end{array}$ & $\begin{array}{l}\text { Using more criteria to critically interpret obtained results of microbiological } \\
\text { analyses gives a more accurate indication of the microbiological performance } \\
\text { of the FSMS }\end{array}$ & 13 & 13 & 12 & $2.1(0.8)$ & $2.4(0.7)$ & $2.4(0.7)$ \\
\hline Advancedness of pesticides sampling & $\begin{array}{l}\text { Structured sampling on both the company and sector levels will provide a more } \\
\text { representative indication of the actual chemical performance of your FSMS }\end{array}$ & 12 & 14 & 11 & $2.1(1.0)$ & $2.4(0.5)$ & $2.2(0.8)$ \\
\hline $\begin{array}{l}\text { Comprehensiveness judgment criteria } \\
\text { chemical FS }\end{array}$ & $\begin{array}{l}\text { Using more criteria to critically interpret obtained results of chemical analyses } \\
\text { provides a more accurate indication of the microbiological performance of the FSMS }\end{array}$ & 12 & 13 & 12 & $2.1(0.9)$ & $2.4(0.5)$ & $2.2(0.8)$ \\
\hline Type of non-conformities ${ }^{a}$ & $\begin{array}{l}\text { Low number or no non conformities indicate a good food safety performance } \\
\text { when a good system for non-conformities registration and evaluation is present }\end{array}$ & 14 & 14 & 13 & $2.1(0.5)$ & $2.7(0.4)$ & $2.4(0.5)$ \\
\hline
\end{tabular}

\footnotetext{
a Indicators retained from the original concept for assessment of FSMS (Jacxsens et al., 2010).

b Modified from the original concept for assessment of FSMS.

c In bold - new indicators added to the main principles for FSMS assessment (Luning et al., 2008).
}

(2.7). For primary production, the highest scores were assigned to indicators about the external evaluation of FSMS through audits (2.6), and complaints on microbiological (2.5) and chemical (2.6) aspects, which is an aspect included in the quality assurance standards for primary production (such as GLOBALGAP). Similarly for trade, experts gave high scores to the indicators for customer complaints regarding microbiological (2.6) and chemical food safety (2.7).

The expert validation confirmed the entire set, and provided information about the representativeness and clarity of each indicator. The experts gave concrete suggestions for improvement, which were used in the version for the companies.

\subsection{Testing in practice}

Fig. 2 illustrates the results from the first testing in three companies in a fresh-cut lettuce production chain. The indicators for the system output gradually increased from primary production to trade, from 3 (moderate output) to 4 (good output). At primary production the levels were 4 (good output) for seriousness of remarks from external FSMS evaluation, microbiological complaints from customers and non-conformities. However, visual complaints and judgment criteria for sampling results for pesticide residues received a level of 2 (poor output), and microbiological sampling received a level of 1 (no data). Indicators aimed at chemical safety (for chemical complaints, and sampling plans for pesticides) received level 4 for both primary production and trade. However, at processing the same indicators received a level of 3 (moderate output), together with the indicators for hygiene and microbiological complaints. Non-conformities and visual complaints were both given a level of 2 . The system output indicators at trade obtained a level 4 , except for seriousness of remarks and non-conformities, which received level 3 , and judgment criteria for pesticide residues sampling, which were evaluated to be level 2 .

Similar to the system output indicators, the levels for FSMS activities increased from 3 (average level) to 4 (advanced level) as we moved further downstream within the production chain, and the trading company was found to be operating at the most advanced levels of control and assurance activities. Control and assurance activities received lower levels (mostly levels 2 and 3 ) at primary production, compared to processing and trade (mostly levels 3 and 4). Many indicators for control activities received a level of 1 , because they were not applied. Examples of such indicators include those for storage facilities, packaging, organic fertilization, microbiological sampling and corrective actions. Crucial activities for primary production, such as water control and pesticide program, obtained level 3, while irrigation method received level 2 . Control activities at processing and trade were mostly assessed with levels of 3 and 4 . A level of 3 (average) was given to the hygienic design of equipment and storage facilities at processing and trade. At processing, many crucial control activities, such as initial material control, supplier control, packaging, water control, and microbial sampling plan, also received level 3. Exceptions were maintenance program, sanitation program, and personal hygiene requirements, which each reached level 4. Assurance activities scored increasingly higher as we moved further downstream in the production chain, with levels of 2-3 at primary production, to 3-4 at processing, and 4 at trade. Validation and verification activities at processing obtained level 3 . At trade most activities received level 4 (advanced level), but the hygienic design of equipment, storage facilities and personal hygiene requirements still were evaluated at level 3, while maintenance program at level 2 .

Overall, the output of the FSMS increases along the production chain, and the trading company operates at advanced levels of control 
Control activities
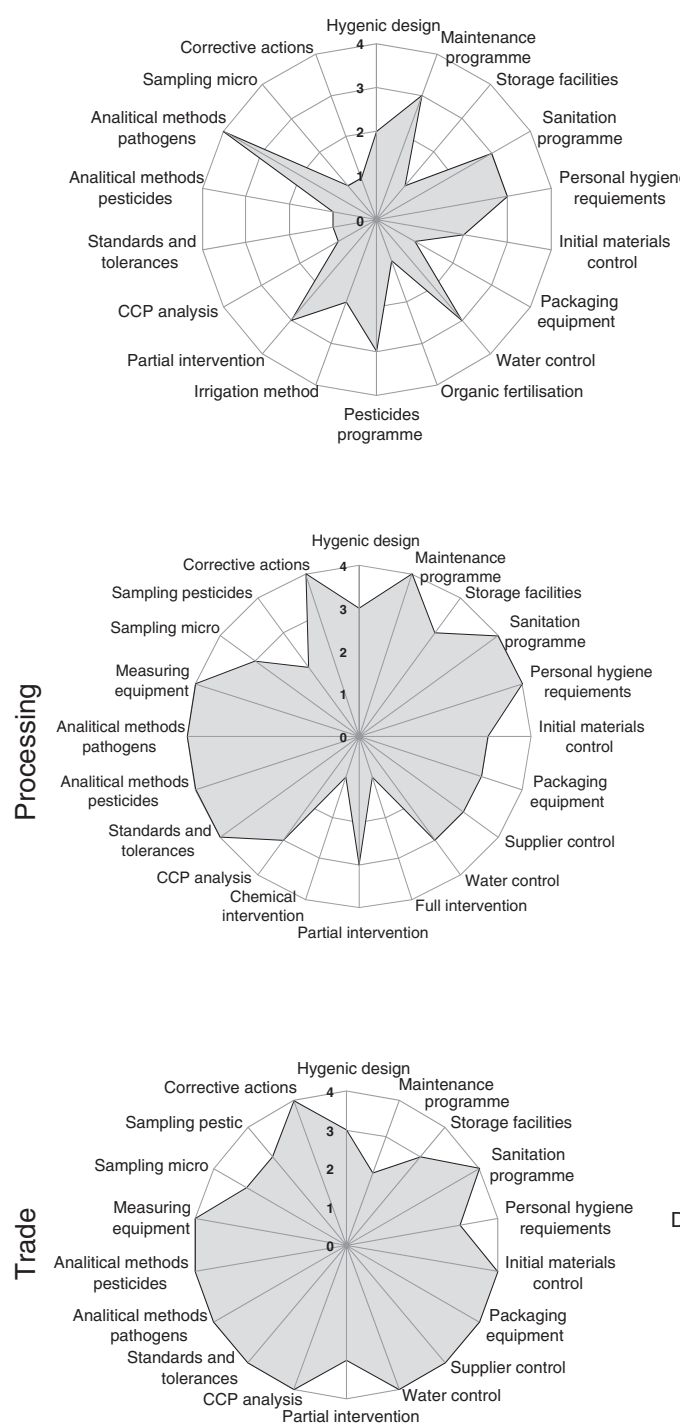

Assurance activities
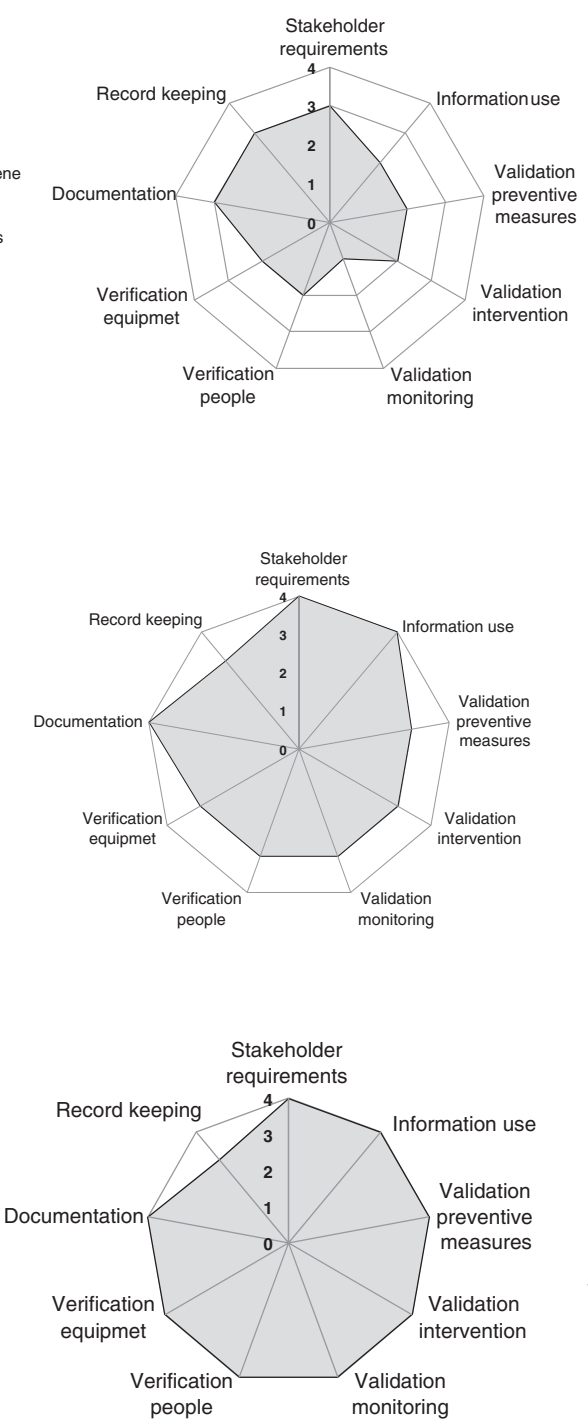
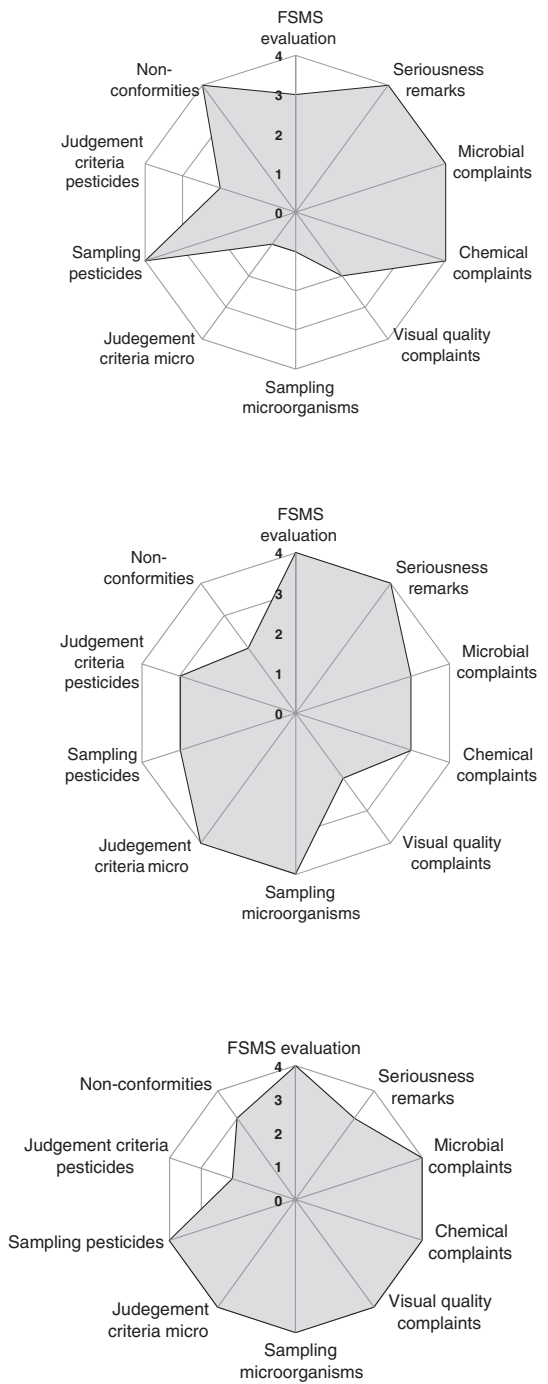

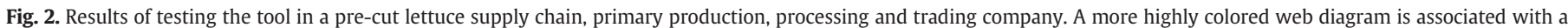
higher, more sophisticated level of control and assurance activities, and better system output.

and assurance activities. At primary production, opportunities for improvement to advanced level (from the detected average levels) lie within several crucial preventive measures (such as water control, irrigation method, pesticide program), and validation of the preventive measures in general. At processing and trade, hygienic design of equipment and facilities, and storage facilities also obtained an average level, meaning that they are not checked or adapted for specific products or company conditions. Moreover, validation and verification received an average level in the processing company, which, together with the average levels for the design of control activities, calls their effectiveness into question. However, the assurance activities achieved the advanced level at trade. Thus, questions arise as to whether implemented in companies' FSMSs are adequately designed and operated, and whether risk is managed at the most appropriate and effective points of the production chain.

The participants in this test stated that, overall, the terms were clear and easy to understand. We have made only minor changes in the definitions and formulations to improve the understanding, especially in the tool for primary production. Furthermore, the tool for primary production was converted into a questionnaire, which improved the understandability and reduced the time for filling in the assessment. When we have communicated the results back to the participants in the assessments, they confirmed that the picture corresponds with the actual situation in the companies.

\section{Conclusions and future perspectives}

The overall objective of this study was to gain insight into the activities that are important for fresh produce and derived food products with respect to microbial and chemical safety. Moreover, an assessment tool was developed to assess the FSMS in the sector, independent from the implemented quality assurance guidelines or standards. The assessment tool addresses crucial control and assurance activities, and shows their underlying mechanisms. It provides an integral and comprehensive assessment of the FSMS, and the system output for individual chain actors and for a supply chain as a whole. It enables the mapping of the FSMS activities, and the analysis of weak and strong points of one FSMS or several FSMSs (for instance in a supply chain, production sector, or region). Users of the tool can recognize the different ways (levels) in which activities can be implemented, and can identify improvement opportunities and see how to develop towards more advanced levels of the FSMS. 
A large-scale application of the tools is ongoing which further confirmed the robustness of the assessment tool, and tested how well the results obtained when using the instrument fitted with the real situation. The tools were translated and assessments were performed in ten countries (Belgium, Brazil, China, Kenya, the Netherlands, Norway, Serbia, South Africa, Spain, Uganda) through individual interviews and workshops. The data from these studies will be presented in the near future.

\section{Acknowledgments}

This research has received funding from the European Community's Seventh Framework Program (FP7) under grant agreement no 244994 (project Veg-i-Trade 'Impact of Climate Change and Globalization on Safety of Fresh Produce - Governing a Supply Chain of Uncompromised Food Sovereignty' www.veg-i-trade.org). We would like to thank Kevin Holvoet for his kind assistance, as well as the experts and companies that participated in the validation process.

\section{References}

Abhilash, P. C., \& Singh, N. (2009). Pesticide use and application: An Indian scenario. Journal of Hazardous Materials, 165(1-3), 1-12.

Alemanno, A. (2010). The European food import safety regime under a stress test: The melamine contamination of the global food supply chain. Erasmus Law Review, 4, 203-215.

Allende, A., Selma, M. V., López-Gálvez, F., Villaescusa, R., \& Gil, M. I. (2008). Role of commercial sanitizers and washing systems on epiphytic microorganisms and sensory quality of fresh-cut escarole and lettuce. Postharvest Biology and Technology, 49(1), 155-163.

Alum, A., Enriquez, C., \& Gerba, C. (2011). Impact of drip irrigation method, soil, and virus type on tomato and cucumber contamination. Food and Environmental Virology, $3(2), 78-85$

Blanc, M. (2006). Sampling: The weak link in the sanitary quality control system of agricultural products. Molecular Nutrition E' Food Research, 50(6), 473-479.

BRC (2008). Global standard for food safety: Guideline for Category 5 fresh produce. BRC Standard.

CAC (2003). Code of hygienic practice for fresh fruits and vegetables. In C. A. Commission (Ed.), CAC/RCP 53-2003.

CAC (2010a). Code of hygienic practice for fresh fruits and vegetables. In C. A Commission (Ed.), Annes III on fresh leafy vegetables. CAC/RCP 53-2003.

CAC (2010b). Codex pesticides residues in food online database. FAO/WHO food standards Codex Alimentarius.

Caduff, L., \& Bernauer, T. (2006). Managing risk and regulation in European food safety governance. Review of Policy Research, 23(1), 153-168.

Chua, D., Goh, K., Saftner, R. A., \& Bhagwat, A. A. (2008). Fresh-cut lettuce in modified atmosphere packages stored at improper temperatures supports enterohemorrhagic $E$. col isolates to survive gastric acid challenge. Journal of Food Science, 73(3), M148-M153.

Coetzer, E. (2005). Microbiological risk in produce from the field to packing. Microbia hazard identification in fresh fruit and vegetables (pp. 73-94). John Wiley \& Sons, Inc.

Cox, J. R. (2002). Pesticide residue analysis facilities: Experiences from the Natura Resource Institute's Support Program. In E. Hanak, E. Boutrif, P. Fabre, \& M Pineiro (Eds.), Food safety management in developing countries. Proceedings of the International Workshop, CIRAD-FAO. Montpellier, France: CIRAD-FAO.

da Cruz, A. G., Cenci, S. A., \& Maia, M. C. A. (2006). Quality assurance requirements in produce processing. Trends in Food Science and Technology, 17(8), 406-411.

de Vaus, D. (2001). Tools for research design. In D. de Vaus (Ed.), Research design in social research. London: SAGE Publications.

EC (2005). Regulation (EC) No 396/2005 of the European Parliament and of the Council of 23 February 2005 on maximum residue levels of pesticides in or on food and feed of plant and animal origin and amending Council Directive 91/414/EEC (Text with EEA relevance). Official Journal of the European Union, L 70, 1-16.

EC (2007). Agricultural commodity markets past developments fruits and vegetables. An analysis of consumption, production and trade based on statistics from the Food and Agriculture Organization (FAO). Vol. Economic analyses and evaluation G.5. European Commission.

EHEDG (2007). Safe and hygienic water treatment in food factories. Trends in Food Science and Technology, 18(Supplement 1), S93-S98.

Ezeike, G., \& Hung, Y. -C. (2009). Chapter 19 - Refrigeration of fresh produce from field to home: Refrigeration systems and logistics. In W. J. Florkowski, R. L. Shewfelt, B. Brueckner, \& S. E. Prussia (Eds.), Postharvest handling (pp. 513-537) (2nd ed.). San Diego: Academic Press.

Fonseca, J. M. (2006). Postharvest handling and processing: Sources of microorganisms and impact of sanitizing procedures. In K. R. Matthews (Ed.), Microbiology of fresh produce (pp. 85-120). Washington, DC: ASM Press.

Fouayzi, H., Caswell, J. A., \& Hooker, N. H. (2006). Motivations of fresh-cut produce firms to implement quality management systems. Applied Economic Perspectives and Policy, 28(1), 132-146.
Froder, H., Martins, C., Lia, G. de Souza, K. L. O, Landgraf, M., Franco, B. D. G. M., et al. (2007). Minimally processed vegetable salads: Microbial quality evaluation. Journal of Food Protection, 70(5), 1277-1280.

Garcia Martinez, M., Poole, N., Skinner, C., Illes, C., \& Lehota, J. (2006). Food safety performance in European union accession countries: Benchmarking the fresh produce import sector in Hungary. Agribusiness, 22(1), 69-89.

Garrett, E. H. (2009). Plant sanitation and good manufacturing practices for optimum food safety in fresh-cut produce. Microbial safety of fresh produce (pp. 307-320). Wiley-Blackwell.

Gentz, M. C., Murdoch, G., \& King, G. F. (2010). Tandem use of selective insecticides and natural enemies for effective, reduced-risk pest management. Biological Control, 52(3), 208-215.

Gerba, C. P., \& Choi, C. Y. (2006). Role of irrigation water in crop contamination by viruses. Viruses in foods (pp. 257-263). US: Springer.

Gerba, C. P., Choi, C. Y., Sapers, G. M., Solomon, E. B., \& Matthews, K. R. (2009). Chapter 5 Water quality. The produce contamination problem (pp. 105-118). San Diego: Academic Press.

Gil, M. I., Selma, M. V., López-Gálvez, F., \& Allende, A. (2009). Fresh-cut product sanitation and wash water disinfection: Problems and solutions. International Journal of Food Microbiology, 134(1-2), 37-45.

GlobalGAP (2012). Integrated Farm Assurance (IFA) standard version 4

Hatanaka, M., Bain, C., \& Busch, L. (2005). Third-party certification in the global agrifood system. Food Policy, 30(3), 354-369.

Havelaar, A. H., Brul, S., de Jong, A., de Jonge, R., Zwietering, M. H., \& Ter Kuile, B. H. (2010). Future challenges to microbial food safety. International Journal of Food Microbiology, 139(Suppl. 1), S79-S94.

Hedberg, C. W., Angulo, F. J., White, K. E., Langkop, C. W., Schell, W. L., Stobierski, M. G., et al. (1999). Outbreaks of salmonellosis associated with eating uncooked tomatoes: Implications for public health. Epidemiology and Infection, 122(3), 385-393.

Hentges, D. L., Schmidt, R. H., \& Rodrick, G. E. (2005). Safe handling of fresh-cut produce and salads. Food safety handbook (pp. 425-442). John Wiley \& Sons, Inc.

Hofer, T., Gardner, B., \& Ford, T. (2005). Fresh produce safety in retail operations. Microbial hazard identification in fresh fruit and vegetables (pp. 245-259). John Wiley \& Sons, Inc.

Holvoet, K., Jacxsens, L., Sampers, I., \& Uyttendaele, M. (2012). Insight into the prevalence and distribution of microbial contamination to evaluate water management in the fresh produce processing industry. Journal of Food Protection, 75(4), 671-681.

Hulebak, K. L., \& Schlosser, W. (2002). Hazard Analysis and Critical Control Point (HACCP) history and conceptual overview. Risk Analysis, 22(3), 547-552.

Hurst, W. C. (2007). Quality assurance and safety consideration for fresh-cut produce. International conference on quality management of fresh cut produce. ISHS Acta Horticulturae, vol. 746. (pp. 115-122).

Iacobucci, D., \& Churchill, G. A. (2010). Marketing research: Methodological foundations. South-Western: Mason, $\mathrm{OH}$ [etc.]

ICMSF (1986). Sampling for microbiological analysis: Principles and specific applications. In I. C. o. M. S. f. Foods (Ed.), Microorganisms in foods 2. Blackwell Scientific Publications.

Ilic, S., Odomeru, J., \& LeJeune, J. T. (2008). Coliforms and prevalence of Escherichia coli and foodborne pathogens on minimally processed spinach in two packing plants. Journal of Food Protection, 71(12), 2398-2403.

Ilic, S., Rajić, A., Britton, C. J., Grasso, E., Wilkins, W., Totton, S., et al. (2012). A scoping study characterizing prevalence, risk factor and intervention research, published between 1990 and 2010, for microbial hazards in leafy green vegetables. Food Control, 23(1), 7-19.

Jacxsens, L., Uyttendaele, M., Devlieghere, F., Rovira, J., Gomez, S. O., \& Luning, P. A. (2010). Food safety performance indicators to benchmark food safety output of food safety management systems. International Journal of Food Microbiology, 141(Supplement 0), S180-S187.

Jaffee, S., \& Masakure, O. (2005). Strategic use of private standards to enhance international competitiveness: Vegetable exports from Kenya and elsewhere. Food Policy, 30(3), 316-333.

James, J. (2005). Overview of microbial hazards in fresh fruit and vegetables operations. Microbial hazard identification in fresh fruit and vegetables (pp. 1-36). John Wiley \& Sons, Inc.

Jamieson, R. C., Gordon, R. J., Sharples, K. E., Stratton, G. W., \& Madani, A. (2002). Movement and persistence of faecal bacteria in agricultural soils and subsurface drainage water: A review. Canadian Biosystem Engineering, 44(1), 1-9.

Johnston, L. M., Jaykus, L. -A., Moll, D., Anciso, J., Mora, B., \& Moe, C. L. (2006). A field study of the microbiological quality of fresh produce of domestic and Mexican origin. International Journal of Food Microbiology, 112(2), 83-95.

Kleter, G. A., \& Marvin, H. J. P. (2009). Indicators of emerging hazards and risks to food safety. Food and Chemical Toxicology, 47(5), 1022-1039.

Lehto, M., Kuisma, R., Määttä, J., Kymäläinen, H. -R., \& Mäki, M. (2011). Hygienic level and surface contamination in fresh-cut vegetable production plants. Food Control, 22(3-4), 469-475.

Leifert, C., Ball, K., Volakakis, N., \& Cooper, J. M. (2008). Control of enteric pathogens in ready-to-eat vegetable crops in organic and 'low input' production systems: A HACCP-based approach. Journal of Applied Microbiology, 105(4), 931-950.

Li, Y., Brackett, R. E., Chen, J., \& Beuchat, L. R. (2002). Mild heat treatment of lettuce enhances growth of Listeria monocytogenes during subsequent storage at $5{ }^{\circ} \mathrm{C}$ or $15{ }^{\circ} \mathrm{C}$. Journal of Applied Microbiology, 92(2), 269-275.

Little, C. L., \& Gillespie, I. A. (2008). Prepared salads and public health. Journal of Applied Microbiology, 105(6), 1729-1743.

Losito, P., Visciano, P., Genualdo, M., \& Cardone, G. (2011). Food supplier qualification by an Italian large-scale-distributor: Auditing system and non-conformances. Food Control, 22(12), 2047-2051. 
Luning, P. A., Bango, L., Kussaga, J., Rovira, J., \& Marcelis, W. J. (2008). Comprehensive analysis and differentiated assessment of food safety control systems: A diagnostic instrument. Trends in Food Science and Technology, 19(10), 522-534.

Luning, P. A., Jacxsens, L., Rovira, J., Osés, S. M., Uyttendaele, M., \& Marcelis, W. J. (2011). A concurrent diagnosis of microbiological food safety output and food safety management system performance: Cases from meat processing industries. Food Control, 22(3-4), 555-565.

Luning, P. A., \& Marcelis, W. J. (2006). A techno-managerial approach in food quality management research. Trends in Food Science and Technology, 17(7), 378-385.

Luning, P. A., \& Marcelis, W. J. (2007). A conceptual model of food quality management functions based on a techno-managerial approach. Trends in Food Science and Technology, 18(3), 159-166.

Luning, P. A., \& Marcelis, W. J. (2009a). A food quality management research methodology integrating technological and managerial theories. Trends in Food Science and Technology, 20(1), 35-44.

Luning, P. A., \& Marcelis, W. J. (2009b). Food quality management: Technological and managerial principles and practice. Enfield Pub \& Distribution Company.

Luning, P. A., Marcelis, W. J., Rovira, J., van Boekel, M. A. J. S., Uyttendaele, M., \& Jacxsens, L. (2011). A tool to diagnose context riskiness in view of food safety activities and microbiological safety output. Trends in Food Science and Technology, 22(Supplement 1), S67-S79.

Luning, P. A., Marcelis, W. J., Rovira, J., Van der Spiegel, M., Uyttendaele, M., \& Jacxsens, L. (2009). Systematic assessment of core assurance activities in a company specific food safety management system. Trends in Food Science and Technology, 20(6-7), 300-312.

Lynch, M. F., Tauxe, R. V., \& Hedberg, C. W. (2009). The growing burden of foodborne outbreaks due to contaminated fresh produce: Risks and opportunities. Epidemiology and Infection, 137(Special Issue 03), 307-315.

McCullough, E. B., Prabhu, P. L., \& Kostas, K. G. (2008). Small farms and the transformation of food systems: An overview. In E. B. McCullough, P. L. Prabhu, \& K. G. Kostas (Eds.), The transformation of agri-food systems: Globalization, supply chains and smallholder farmers. Routledge.

Michaels, B., \& Todd, E. (2005). Food worker personal hygiene requirements during harvesting, processing, and packaging of plant products. Microbial hazard identification in fresh fruit and vegetables (pp. 115-153). John Wiley \& Sons, Inc.

Millner, P. D. (2009). Manure management. In G. M. Sapers, E. B. Solomon, \& K. R. Matthews (Eds.), The produce contamination problem (pp. 79-104). San Diego: Academic Press.

Moral, R., Paredes, C., Bustamante, M. A., Marhuenda-Egea, F., \& Bernal, M. P. (2009). Utilisation of manure composts by high-value crops: Safety and environmental challenges. Bioresource Technology, 100(22), 5454-5460.

Okello, J. J., \& Swinton, S. M. (2007). Compliance with International Food Safety Standards in Kenya's green bean industry: Comparison of a small- and a large-scale farm producing for export. Applied Economic Perspectives and Policy, 29(2), 269-285.

Okello, J. J., \& Swinton, S. M. (2010). From circle of poison to circle of virtue: Pesticides, export standards and Kenya's green bean farmers. Journal of Agricultural Economics, 61(2), 209-224

Olivet, J. J., Val, L., \& Usera, G. (2011). Distribution and effectiveness of pesticide application with a cold fogger on pepper plants cultured in a greenhouse. Crop Protection, 30(8), 977-985.

Oron, G., Campos, C., Gillerman, L., \& Salgot, M. (1999). Wastewater treatment, renovation and reuse for agricultural irrigation in small communities. Agricultural Water Management, 38(3), 223-234.

Osés, S. M., Luning, P. A., Jacxsens, L., Santillana, S., Jaime, I., \& Rovira, J. (2012). Food safety management system performance in the lamb chain. Food Control, 25(2), 493-500.

Pachepsky, Y., Shelton, D. R., McLain, J. E. T., Patel, J., Mandrell, R. E., \& Donald, L. S. (2011). Irrigation waters as a source of pathogenic microorganisms in produce: A review. Chapter two. Advances in agronomy, vol. 113. (pp. 73-138): Academic Press.

Rapanello, E., Fuzihara, T. O., Nunes, S. M., Daros, V. d. S. M. G., \& Savignano, L. V. (2009). Hygienic conditions of minimally-processed watercress, lettuce and cabbage, and fresh-cut lettuce. Revista do Instituto Adolfo Lutz (Impresso), 68, 83-90.

Rediers, H., Claes, M., Peeters, L., \& Willems, K. A. (2009). Evaluation of the cold chain of fresh-cut endive from farmer to plate. Postharvest Biology and Technology, 51(2), 257-262.
Roth, A. V., Tsay, A. A., Pullman, M. E., \& Gray, J. V. (2008). Unraveling the food supply chain: Strategic insights from China and the 2007 recalls. Journal of Supply Chain Management, 44(1), 22-39.

Sagoo, S. K., Little, C. L., \& Mitchell, R. T. (2003). Microbiological quality of open ready-to-eat salad vegetables: Effectiveness of food hygiene training of management. Journal of Food Protection, 66(9), 1581-1586.

Santamaría, J., \& Toranzos, G. A. (2003). Enteric pathogens and soil: A short review. International Microbiology, 6(1), 5-9.

Seymour, I. J. (1999). Review of current industry practice on fruit and vegetable decontamination. Report of. Chippin Campden, Gloucestershire: Campden and Chorleywood Food Research Association Group.

Siddiqi, Z. (2010). 7 Steps to an effective pest management program. Food Quality, AugustSeptember.

Sivapalasingam, S., Friedman, C. R., Cohen, L., \& Tauxe, R. V. (2004). Fresh produce: A growing cause of outbreaks of foodborne illness in the United States, 1973 through 1997. Journal of Food Protection, 67(10), 2342-2353.

Soon, J. M., \& Baines, R. N. (2012). Food safety training and evaluation of handwashing intention among fresh produce farm workers. Food Control, 23(2), 437-448.

Starbird, S. A. (2005). Supply chain contracts and food safety. Choices: The magazine of food, farm, and resource, issues, $20(2)$.

Steele, M., Mahdi, A., \& Odumeru, J. (2005). Microbial assessment of irrigation water used for production of fruit and vegetables in Ontario, Canada. Journal of Food Protection, 68(7), 1388-1392.

Steele, M., \& Odumeru, J. (2004). Irrigation water as source of foodborne pathogens on fruit and vegetables. Journal of Food Protection, 67(12), 2839-2849.

Stine, S. W., Song, I., Choi, C. Y., \& Gerba, C. P. (2005). Effect of relative humidity on preharvest survival of bacterial and viral pathogens on the surface of cantaloupe, lettuce, and bell peppers. Journal of Food Protection, 68(7), 1352-1358.

Tauxe, R. V., Doyle, M. P., Kuchenmüller, T., Schlundt, J., \& Stein, C. E. (2010). Evolving public health approaches to the global challenge of foodborne infections. International Journal of Food Microbiology, 139(Supplement 0), S16-S28.

Taylor, E., Kastner, J., \& Renter, D. (2010). Challenges involved in the Salmonella Saintpaul outbreak and lessons learned. Journal of Public Health Management and Practice, 16(3), 221-231.

Thorpe, S. A., \& Reynolds, S. L. (1996). Accreditation in the UK for pesticide residue analysis in foods. Journal of Chromatography. A, 737(1), 3-7.

Todd, E. C. D., Greig, J. D., Michaels, B. S., Bartleson, C. A., Smith, D., \& Holah, J. (2010). Outbreaks where food workers have been implicated in the spread of foodborne disease. Part 11. Use of antiseptics and sanitizers in community settings and issues of hand hygiene compliance in health care and food industries. Journal of Food Protection, 73(12), 2306-2320.

Todd, E. C. D., Michaels, B. S., Greig, J. D., Smith, D., Holah, J., \& Bartleson, C. A. (2010). Outbreaks where food workers have been implicated in the spread of foodborne disease. Part 7. Barriers to reduce contamination of food by workers. Journal of Food Protection, 73(8), 1552-1565.

Trienekens, J., \& Zuurbier, P. (2008). Quality and safety standards in the food industry, developments and challenges. International Journal of Production Economics, 113(1), $107-122$.

Tyrrel, S. F., Knox, J. W., \& Weatherhead, E. K. (2006). Microbiological water quality requirements for salad irrigation in the United Kingdom. Journal of Food Protection, $69,2029-2035$.

UnitedFresh (2008). Commodity specific food safety guidelines for the fresh tomato supply chain. Guideline of: United Fresh.

van Asselt, E. D., Meuwissen, M. P. M., van Asseldonk, M. A. P. M., Teeuw, J., \& van der Fels-Klerx, H. J. (2010). Selection of critical factors for identifying emerging food safety risks in dynamic food production chains. Food Control, 21(6), 919-926.

Van Boxstael, S., Habib, I., Jacxsens, L., De Vocht, M., Baert, L., Van De Perre, E., et al (2013). Food safety issues in fresh produce: Bacterial pathogens, viruses and pesticide residues indicated as major concerns by stakeholders in the fresh produce chain. Food Control, 32(1), 190-197.

WesternGrowers (2006). Commodity specific food safety guidelines for the lettuce and leafy greens supply chain. Guideline of: Western Growers.

Yudin, R. (2011). The realities of good agricultural practices certification. Acta Horticulturae Proceedings International Conference on postharvest and quality management of horticultural products of interest for tropical regions (906). 